\title{
Adult sex ratios of loggerhead sea turtles (Caretta caretta) in two Mediterranean foraging grounds
}

\author{
Paolo Casale ${ }^{1,2}$, Daniela Freggi ${ }^{3}$, Fulvio Maffucci ${ }^{4,5}$, Sandra Hochscheid ${ }^{4}$ \\ ${ }^{1}$ Department of Biology and Biotechnologies "Charles Darwin", University of Rome "La Sapienza", viale dell'Università \\ 32, 00185 Rome, Italy. E-mail: paolo.casale1@gmail.com \\ ${ }^{2}$ Centre for Ecology and Conservation, University of Exeter, Cornwall Campus, TR10 9EZ, UK \\ ${ }^{3}$ Sea Turtle Rescue Centre WWF Italy, Lampedusa, Italy. \\ ${ }^{4}$ Stazione Zoologica Anton Dohrn, Villa Comunale, 80121 Naples, Italy. \\ ${ }^{5}$ Dipartimento di Scienze" Università Roma Tre, Viale G. Marconi 446, 00146 Rome, Italy.
}

\begin{abstract}
Summary: Sea turtles show temperature-dependent sex determination (TSD) and information on sex ratios at different life stages is necessary both for population dynamics models for conservation and to shed light on the possible adaptive value of TSD. Adults represent the less abundant class of sea turtle populations and adult sex ratios at foraging grounds are very difficult to obtain. We first analysed biometric data of 460 juvenile and adult loggerhead sea turtles ranging from 60 to 97.5 $\mathrm{cm}$ curved carapace length $(\mathrm{CCL})$, in which a clear bimodal distribution of tail length (the main secondary sexual character of adult males) was observed in the size class $>75 \mathrm{~cm} \mathrm{CCL}$. We then sexed 142 adult turtles in this size class collected from the Tunisian shelf and from the southeastern Tyrrhenian Sea, observing a proportion of females of 51.5\% (95\% CI: 41.2-61.8\%; $\mathrm{n}=97)$ and $40.0 \%$ (95\% CI: $25.7-55.7 \%$; $n=45)$ respectively. Our results complement previous studies and support their findings of similar and more balanced sex ratios in adult and juvenile loggerhead turtles in the Mediterranean, in contrast with highly female-biased sex ratios of hatchlings.
\end{abstract}

Keywords: Caretta caretta; sea turtle; adult; sex ratio; maturity; temperature-dependent sex determination; Mediterranean.

Proporción de sexos para adultos de tortugas marinas (Caretta caretta) en dos áreas de alimentación mediterráneas

Resumen: El sexo de las tortugas marinas viene determinado por la temperatura (TSD) y la información sobre la proporción de sexos en las diferentes etapas de la vida es necesaria, tanto para los modelos de dinámica de poblaciones para su conservación como para conocer el posible valor adaptativo a TSD. Los adultos representan la clase menos abundante de las poblaciones de tortugas marinas y la proporción de sexos para adultos en las áreas de alimentación son muy difíciles de obtener. En primer lugar, analizamos los datos biométricos de 460 jóvenes y adultos de tortugas bobas marinas en que la longitud del caparazón curvado (LCC) oscilaba entre 60 y $97.5 \mathrm{~cm}$, donde se observó una distribución bimodal clara de la longitud de la cola (el carácter sexual secundario principal del macho adulto) en la clase de tamaño $>75 \mathrm{~cm}$ de CCL. A continuación, sexamos 142 tortugas adultas en esta clase de tamaño obtenida en la zona de plataforma de Túnez y desde el sureste del mar Tirreno, observando una proporción de hembras del 51.5\% (IC del 95\%: 41.2 a 61.8\%, n=97) y 40,0\% (IC del 95\%: 25,7 a $55.7 \%, \mathrm{n}=45$ ), respectivamente. Nuestros resultados complementan estudios previos y apoyan una proporción de sexos similares y más equilibrados en tortugas bobas adultas y juveniles en el Mediterráneo, en contraposición con la proporción de sexos altamente sesgados de hembras de las crías.

Palabras clave: Caretta caretta; tortuga marina; adulto; proporción de sexos; madurez; determinación de sexo determinado por la temperatura; Mediterráneo.

Citation/Como citar este artículo: Casale P., Freggi D., Maffucci F., Hochscheid S. 2014. Adult sex ratios of loggerhead sea turtles (Caretta caretta) in two Mediterranean foraging grounds. Sci. Mar. 78(2): 303-309. doi: http://dx.doi.org/10.3989/ scimar.03988.30E

Editor: D. Oro.

Received: December 3, 2013. Accepted: February 21, 2014. Published: May 30, 2014.

Copyright: () 2014 CSIC. This is an open-access article distributed under the Creative Commons Attribution-Non Commercial Lisence (by-nc) Spain 3.0.

\section{INTRODUCTION}

The sex of sea turtles is determined by the temperature to which an embryo is exposed during its develop- ment (Wibbels 2003), as in many other reptiles (Janzen and Paukstis 1991). In general, skewed sex ratios are more common in species with temperature-dependent sex determination (TSD) than in species with a geno- 
typic sex determination (Bull 1980). Sea turtles are no exception and female-biased sex ratios are observed in most cases (Wibbels 2003). The adaptive value of TSD and skewed sex ratios is puzzling. Fisher (1930) elegantly explained why natural selection favours equal parental investment towards both sexes. However, in most reptiles with TSD parental care ends before sexual determination, therefore whether the parents or the offspring are the subject of selective pressures for adjusting sex through TSD is a key question for developing evolutionary models (e.g. Charnov and Bull 1977, Mrosovsky and Provancha 1992). A good sampling of natural sex ratios and possible sex ratio variability among species and populations is necessary to shed light on the evolutionary basis of TSD in sea turtles (Mrosovsky 1994, Freedberg and Wade 2001). Sex ratio must also be considered in population dynamics of species with TSD, since important parameters such as population size and reproductive output can only be estimated if several demographic parameters, including sex ratio, are available for the models (e.g. Heppell et al. 2003). Since sea turtles are species of conservation concern, this is particularly important for understanding how they may respond to both anthropogenic threats and conservation measures. Unfortunately, sex ratio is not easy to assess in sea turtles, and this leads to increased uncertainty in population models.

For convenience, three major life stages (hatchlings, juveniles, and adults) can be distinguished when one is investigating sea turtle sex ratios and different methods are used for different stages. Hatchling sex ratio is the most easy to obtain, either directly by examining their gonads (e.g. Yntema and Mrosovsky 1980), or indirectly from nest temperature or other variables associated with nest temperature (e.g. Mrosovsky et al. 1999). Juveniles can be sampled in relatively high numbers when they strand, are incidentally caught in fishing gear or are directly captured at sea. Then they can be sexed using different methods such as blood hormonal dosage, histology and direct observation of gonadal morphology by laparoscopy or during necropsies (Wibbels 1999). Only adults show external sexual dimorphism, notably an elongated tail in males, so it is relatively easy to sex them (Casale et al. 2005). Unfortunately, they represent the least abundant class of sea turtle populations, so sampling adults at foraging areas is intrinsically difficult. Adults can be found in high numbers and densities when they aggregate at mating sites near nesting beaches during the breeding season (e.g. Schofield et al. 2009). However, the sex ratios observed at these sites (operational sex ratios) may not represent the actual adult sex ratio of their population because of possible different breeding periodicity of males and females (Miller 1997, Stewart and Dutton 2011, Wright et al. 2012). Therefore, more reliable adult sea turtle sex ratios can be assessed at foraging grounds where, however, they are very difficult to collect because of their low abundance. For these reasons, juvenile sex ratios, adult sex ratios at foraging grounds and operational sex ratios should be investigated separately.
The loggerhead turtle (Caretta caretta) is the most abundant sea turtle species in the Mediterranean, and reproduces mainly in Greece, Turkey, Cyprus and Libya (Casale and Margaritoulis 2010). Loggerhead turtles frequent the entire marine area of the Mediterranean Sea. Oceanic zones are mainly frequented by small juveniles and a high occurrence is reported in the westernmost part of the basin (from the Alboran Sea to the Balearic Islands), the Strait of Sicily, and the Ionian Sea. Larger juveniles and adults tend to frequent neritic zones, with high occurrence observed in the north Adriatic, off Tunisia-Libya, off Egypt, and off the southeast coast of Turkey (Casale and Margaritoulis 2010). One of the most distinctive characteristics of the Mediterranean population is the significantly smaller adult size in comparison with other populations around the world (Dodd 1988, Tiwari and Bjorndal 2000, Margaritoulis et al. 2003): on average Mediterranean loggerhead turtles mature at a size larger than $70 \mathrm{~cm}$ curved carapace length (Margaritoulis et al. 2003, Casale et al. 2005).

The first attempt to estimate sex ratios of adult loggerhead sea turtles in the Mediterranean was based on individuals collected from a wide area all around the Italian peninsula (Casale et al. 2005). More recently, genetic markers showed that individuals originating from different nesting sites distribute differently among neritic foraging areas, i.e. turtles from a certain rookery prevalently frequent certain areas and turtles from another rookery prevalently frequent other areas (Garofalo et al. 2013, Clusa et al. in press). Moreover, satellite tracking showed a high degree of fidelity of loggerhead turtles, in particular adults, to specific neritic areas (Broderick et al. 2007, Schofield et al. 2010, Casale et al. 2012, Casale et al. 2013, Rees et al. 2013). Therefore, different adult sex ratios can be associated with different neritic areas and should be preferably assessed at local level first, then at regional level. As said, the most limiting factor is the rarity of adults at foraging grounds and so far one study has reported an adult sex ratio from a specific foraging ground: the Gulf of Amvrakikos, Greece (Rees et al. 2013). Operational sex ratios have been investigated only at one breeding site (Zakynthos, Greece), where a relatively balanced operational sex ratio was estimated (Hays et al. 2010).

Genetic markers (Garofalo et al. 2013), tag returns (Margaritoulis et al. 2003) and satellite tracking (Broderick et al. 2007, Casale et al. 2013, Schofield et al. 2013) showed that the continental shelf off Tunisia and Libya is one of the most important neritic foraging grounds in the Mediterranean and is frequented by loggerhead juveniles and adults originating from different Mediterranean breeding sites in Greece, Libya, and Cyprus. In the western Mediterranean, loggerhead turtles are also commonly encountered along the southwestern coasts of Italy in the Tyrrhenian Sea. Mediterranean juveniles and adults utilize the rich local swallow habitats of this area to forage (Hochscheid et al. 2013, Maffucci et al. 2013, Clusa et al. in press). This study aims to provide estimations of adult sex ratios of loggerhead turtles at the above two foraging grounds. 


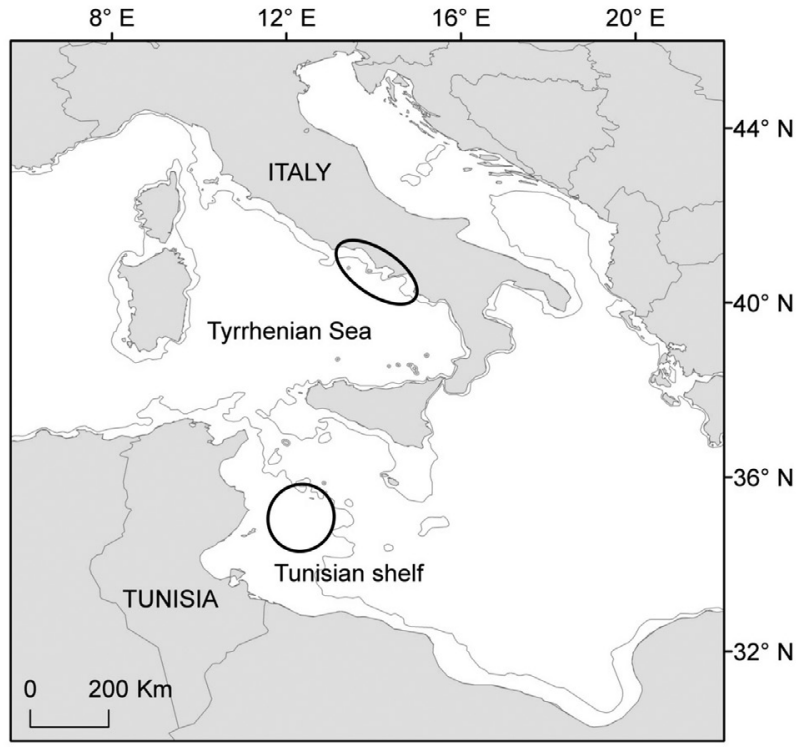

Fig. 1. - Central Mediterranean. The two neritic foraging areas where juvenile and adult loggerhead turtles were collected are approximately shown by ellipses: the southeastern Tyrrhenian and the Tunisian shelf. The 200-m isobath, conventionally indicating the continental shelf, is also shown.

\section{MATERIALS AND METHODS}

A total of 505 loggerhead turtles were considered in this study. They were incidentally captured by fishing gear $(n=419)$, found stranded $(n=32)$, found floating at sea $(n=52)$, or found while nesting $(n=2)$. They were collected from two areas: the waters around Lampedusa island, Italy, on the Tunisian shelf, in the period 1991-2012 $(n=460)$, and the southeastern Tyrrhenian Sea in the period 2000-2013 (n=45) (Fig. 1). The above sampling methods, except nesting, are assumed not to be sex-biased, i.e. the probability of being incidentally captured, or of stranding or to be found floating at sea in foraging areas is the same for both sexes. However, for 16 turtles this assumption was not valid; they were therefore excluded from sex ratio analysis (see below) and were only considered for setting up the sexing method. Sample size prevented interannual sex ratio differences from being assessed and for convenience sex ratios were assumed to be constant during the study period.

These data were used in a three-step process aimed at estimating adult sex ratios. The first step analysed biometric data of turtles in the size range of juveniles and adults in order to assess a good threshold for the adult size, i.e. the size above which almost all turtles are mature and a turtle with a short tail (the main sexually dimorphic character) is unlikely to be an immature male and is likely to be a mature female. In order to improve detection of the appearance of the main sexually dimorphic character (tail length) and to interpret this character also in the light of reference values for adult females recently made available (Rees et al. 2013), we analysed biometric data of 460 loggerhead turtles ranging from 60 to $97.5 \mathrm{~cm}$ curved carapace length (CCL). This part of the study was conducted only in one area, the Tunisian shelf, where a suitable sample of turtles was available. We limited the analysis to the range $>60 \mathrm{~cm}$ CCL because previous studies (Casale et al. 2005, Rees et al. 2013) showed that on average loggerhead males begin to develop an elongated tail around $65 \mathrm{~cm}$ of CCL notch-to-tip (Bolten 1999), so the threshold size for adulthood is expected to be above $65 \mathrm{~cm}$ CCL. The second step determined a good threshold of tail length for sexing adults, i.e. the tail length above and below which a turtle can be considered as male or female, respectively. This threshold value was determined on the basis of the bimodal distribution of tail lengths observed in the adult size class and compared with previous similar studies in the region (Casale et al. 2005, Rees et al. 2013). The third step estimated sex ratios of 142 turtles in the adult size class ( 97 from the Tunisian shelf and 45 from the Tyrrhenian Sea), after removing 16 turtles ( 9 males and 7 females) because their finding was probably not independent from their sex. Turtles were sexed either by tail length, as described above, or by other methods, as follows. All turtles collected from the Tunisian shelf (all alive; $n=97$ ) were sexed according to the distance from the posterior margin of the carapace to the tip of the tail (carapace-tail) and the distance from the posterior margin of the carapace to the cloaca (carapace-cloaca), which were previously proposed as the best indicators of sex in adult individuals (Casale et al. 2005). Twelve live turtles collected in the Tyrrhenian were sexed according to one of the above tail measures, depending on the individual cases. In four of these turtles, photographs were used to determine whether carapace-cloaca was $>0$ (the sexing threshold), i.e. whether the cloaca was internal or external to the carapace, which can be easily determined by eye. The sex of 33 other dead turtles from the Tyrrhenian was determined through visual examination of the gonads during necropsies. Before release, all live turtles were tagged with metal or plastic flipper tags (Balazs 1999) to avoid replication.

Adult sex ratios at foraging grounds can be biased by sex-specific breeding periodicity, and to avoid this bias it is preferable to estimate sex ratios outside the breeding period (Wibbels 2003). However, in the Mediterranean adult males start migrating to breeding sites as early as October and migrate back to foraging grounds towards May (Hays et al. 2010, Schofield et al. 2010, Casale et al. 2013), while adult females arrive at breeding sites towards April (Hays et al. 2010) and return to foraging grounds as late as October (Zbinden et al. 2011). Hence, one sex or the other is always expected to be underrepresented at foraging grounds. In order to consider potential seasonal differences in sex ratios, we also calculated sex ratios for two periods: when more males are expected at foraging grounds (Jun-Sep) and when more females are expected (Oct-Mar).

We calculated $95 \%$ confidence intervals of sex ratios according to the method for binomial distributions (Zar 1999). Pairwise statistical tests between seasons and among known sex ratios of hatchling, juvenile and adult loggerheads in the Mediterranean were conducted by Fisher exact test on $2 \times 2$ contingency tables with the observed numbers of individuals. CCL values were 


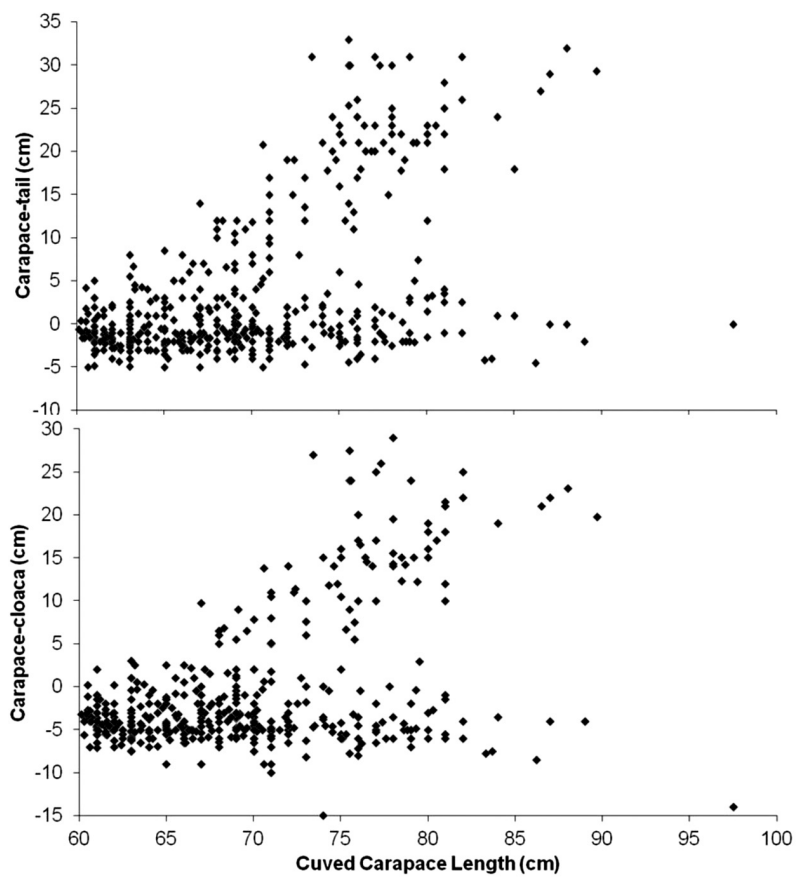

Fig. 2. - Distribution according to curved carapace length of two measures of the tail (carapace-tail and carapace-cloaca) of $460 \mathrm{log}$ gerhead sea turtles from the Tunisian shelf, central Mediterranean.

compared with straight carapace length (SCL) values from other studies by the conversion equation provided by Bjorndal et al. (2000): $\mathrm{CCL}=1.388+1.053 \mathrm{SCL}$.

\section{RESULTS}

In the sample from the Tunisian shelf, the distribution of carapace-tail and carapace-cloaca values by CCL (Fig. 2) and the frequency distribution of these two measures in different 5-cm CCL classes (Fig. 3) show that an elongated tail starts to be common at 65$75 \mathrm{~cm}$ CCL, but a clear bimodal distribution only arises at $>75 \mathrm{~cm}$ CCL. Comparison between the $75-80 \mathrm{~cm}$ CCL and $>80 \mathrm{~cm}$ CCL size classes (Fig. 3) indicates that the two sexes are similarly differentiated in both size classes, so adopting $75 \mathrm{~cm}$ as the adult threshold is the best trade-off between sample size and sexual dimorphism.

On the basis of the observed bimodal distributions, good threshold values for determining sex are $5 \mathrm{~cm}$ and $0 \mathrm{~cm}$ for carapace-tail and carapace-cloaca, respectively, as previously suggested (Casale et al. 2005). This is consistent with the maximum tail length $(7 \mathrm{~cm})$ observed among 94 nesting females (Rees et al. 2013), since the latter measure was taken from the notch between the supracaudal scutes (vs. the tip of the supracaudal scutes in this study) and therefore it is slightly longer $(\mathrm{ca} .1-3 \mathrm{~cm})$ than the measure considered in this study (carapace-tail).

The proportion of females among turtles $>75 \mathrm{~cm}$ CCL was $51.5 \%$ (95\% CI: 41.2-61.8\%; $n=97)$ in the Tunisian shelf sample and 40.0\% (95\% CI: $25.7-55.7 \%$; $\mathrm{n}=45$ ) in the Tyrrhenian sample, and the two were not found to be significantly different (Fisher exact test; $\mathrm{p}=0.17 ; \mathrm{n}=142)$. No significant differences were ob- served between the two periods of the year (Jun-Sep and Oct-Mar) within the same sample: $46.0 \%$ (95\% CI: $33.4-59.1 \%$; $n=63$ ) in Jun-Sep and $61.8 \%$ in Oct-Mar (95\% CI: 43.6-77.8\%; $n=34$ ) in the Tunisian shelf sample (Fisher exact test; $\mathrm{p}=0.20 ; \mathrm{n}=97)$ and $50.0 \%(95 \%$ CI: $28.2-71.8 \%$; $n=22)$ in Jun-Sep and $31.6 \%$ (95\% CI: $12.6-56.6 \% ; n=19)$ in Oct-Mar in the Tyrrhenian sample (Fisher exact test; $p=0.34 ; n=41$ ). However, while the sex ratios from the two areas were similar in JunSep (Fisher exact test; $\mathrm{p}=0.81 ; \mathrm{n}=85$ ) they were different in Oct-Mar, with fewer females in the Tyrrhenian sample (Fisher exact test; $\mathrm{p}<0.05 ; \mathrm{n}=53$ ).

\section{DISCUSSION}

The two sex ratios observed in this study are not significantly different from the other adult sex ratios in single foraging grounds (Ionian Greece) or from juvenile sex ratios in different areas, except for the adult vs. juvenile sex ratios in the Tyrrhenian Sea (Table 1). However, they differ from one or two (depending on the study area) hatchling sex ratios for which a statistical comparison is possible (Table 1). On the basis of incubation duration, Godley et al. (2001a) hypothesized that a female-biased hatchling sex ratio is produced in most of the major nesting sites of the Mediterranean. In fact, all the specific studies conducted so far in major nesting sites in Greece, Turkey and Cyprus estimated a high female proportion (Table 1). On the other hand, juvenile sex ratios appear to be more balanced, and adult sex ratios are even male-biased in two cases: in the Tyrrhenian and in the Amvrakikos Gulf (Table 1). However, these two cases are probably different, because in the Tyrrhenian the male bias was only observed in the period October-March, while the sex ratio in the Amvrakikos Gulf refers to the period May-September, this being the only period sampled there (Rees et al. 2013). Therefore, data from the Amvrakikos Gulf and from the Tunisian shelf in the period June-September are somehow in line with the expectations: less females in June-September at foraging grounds (see above). By contrast, the male bias observed in the Tyrrhenian in the period Oct-March is intriguing and deserves further investigation. Sample size may limit the capability of detecting differences in some cases, and larger samples from different seasons and foraging areas are needed to unveil adult sex ratio patterns and their possible differences from juvenile sex ratios in the Mediterranean. On the other hand, there is an obvious difference between the hatchling and juvenile/adult sex ratios known so far. A similar discrepancy has also been observed in the northwest Atlantic (Wibbels 2003). Three general cases can explain this discrepancy: (i) the available sex ratios are representative of the population demography and post-hatchling/juvenile females experience a higher mortality than males; (ii) the current juvenile and adult sex ratios are not representative of the entire population and higher female-biased sex ratios occur in foraging areas not yet investigated; (iii) the current hatchling sex ratios are not representative of the entire population and more balanced or male-biased sex ratios are produced in under-studied periods or beach 

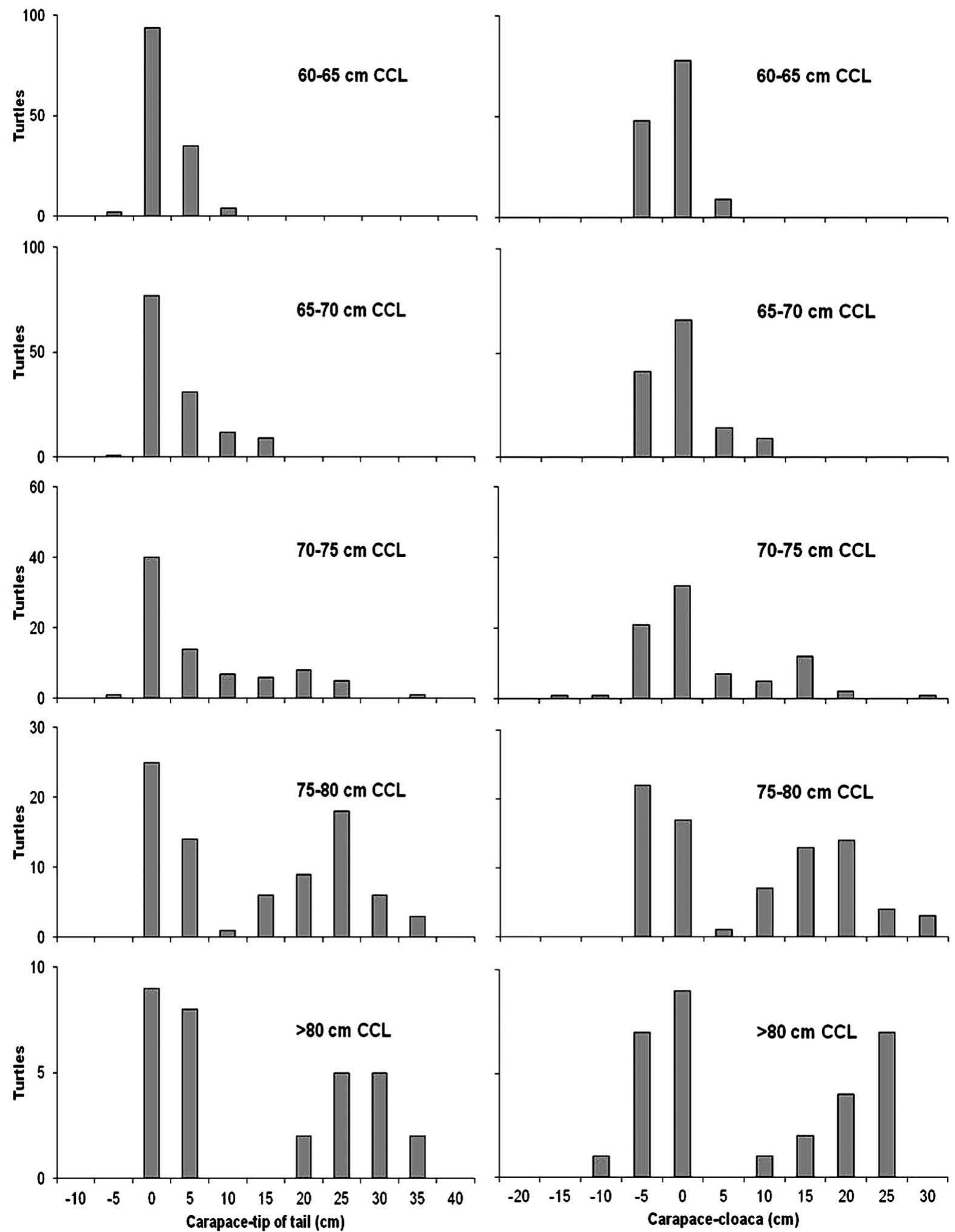

Fig. 3. - Frequency distribution of two measures of the tail (carapace-tail and carapace-cloaca) in different 5-cm size classes (curved carapace length, CCL) of 460 loggerhead sea turtles from the Tunisian shelf, central Mediterranean.

sectors, or at other nesting sites, including minor sites and areas with diffuse nesting.

Adult sex ratios at breeding grounds (operational sex ratios) will reflect sex ratios at foraging grounds only if the breeding periodicity of males and females is similar. In the Mediterranean, operational sex ratios have been investigated only at the Zakynthos breeding site (Greece) where a relatively balanced operational sex ratio (43\% females) is estimated (Hays et al. 2010). This value is fairly similar to the sex ratios observed at the foraging grounds investigated so far and would suggest a similar breeding periodicity of males and fe- 
Table 1. - Known sex ratios of different life stages (hatchlings, juveniles and adults) of loggerhead sea turtles in the Mediterranean. Hatchling sex ratios are from nesting beaches while juvenile and adult sex ratios are from foraging areas. Sex ratios where real numbers of males and females are available (i.e. where $\mathrm{n}$ is shown) were compared (Fisher exact test), and those significantly different are indicated as follows: * this sex ratio resulted different $(\mathrm{p}<0.01)$ in all the pairwise tests with the other values; five pairs of sex ratio values which differed with $\mathrm{p}<0.05$ are indicated by five pairs of the symbols $\langle, \square,+, \S, 0$.

\begin{tabular}{|c|c|c|c|c|}
\hline Category & Area & Method & $\begin{array}{l}\text { Proportion of females }(\%) \\
(95 \% \mathrm{CI} ; \mathrm{n})\end{array}$ & Source \\
\hline \multirow[t]{4}{*}{ Adults (>75 cm CCL) } & Central Mediterranean & Tail length & 51.5 (41.2-61.8; 97) & present study \\
\hline & Southeast Tyrrhenian & Gonads (gross morphology) & 40.0 (25.7-55.7; 45)內 $\square$ & present study \\
\hline & Amvrakikos Gulf & Tail length & $43.9(34.3-53.9 ; 107)+\S \circ$ & Rees et al. (2013) \\
\hline & Italy (all marine areas) & Tail length & $60.9(48.4-72.4 ; 69) \circ$ & Casale et al. (2005) \\
\hline \multirow[t]{6}{*}{ Juveniles } & Central Mediterranean & Blood hormones & $55.6(41.4-69.1 ; 54)$ & Casale et al. (1998) \\
\hline & & Gonads (gross morphology) & $54.5(41.8-66.9 ; 66)$ & Casale et al. (2006) \\
\hline & Northwest Mediterranean & Gonads (gross morphology) & $53.8(43.8-63.7 ; 104)$ & Casale et al. (2006) \\
\hline & Southwest Adriatic & Gonads (gross morphology) & $51.8(40.6-62.9 ; 83)$ & Casale et al. (2006) \\
\hline & Nord-East Adriatic & Gonads (gross morphology) & $57.9(44.1-70.9 ; 57)$ & Casale et al. (2006) \\
\hline & Southeast Tyrrhenian & Gonads (gross morphology) & $61.0(54.2-67.5 ; 218)+\downarrow$ & Maffucci et al. (2013) \\
\hline \multirow[t]{10}{*}{ Hatchlings } & Zakynthos, Greece & Incubation duration & $68-75$ & Zbinden et al. (2007) \\
\hline & & Incubation duration & $73.2-80.6$ & Katselidis et al. (2012) \\
\hline & Kyparissia, Greece & Sand temperature & 70 & Rees and Margaritoulis (2004) \\
\hline & Anamur, Turkey & Incubation duration & 85.2 & Uçar et al. (2012) \\
\hline & & Gonads (histology) & $75(71.5-78.4 ; 637)^{*}$ & Uçar et al. (2012) \\
\hline & Fethiye, Turkey & Sand temperature & 60.8 & Kaska et al. (2006) \\
\hline & & Incubation duration & 60 & Kaska et al. (2006) \\
\hline & & Gonads (histology) & $64.7(53.6-74.8 ; 85) \S \square$ & Kaska et al. (2006) \\
\hline & Patara, Turkey & Nest temperature & 70.5 & Oz et al. (2004) \\
\hline & Alagadi, Cyprus & Incubation duration & $89-99$ & Godley et al. (2001b) \\
\hline
\end{tabular}

males. However, there are indications that males breed more often than females (Hays et al. 2010), although the degree of such a difference was recently questioned with a male breeding periodicity (Casale et al. 2013) that would be compatible with the sex ratio observed on the Tunisian shelf. Therefore, the available information on adult sex ratios and breeding behaviour in the Mediterranean is clearly still insufficient to unveil complex patterns, such as different sex ratios among foraging areas and different sex-specific breeding periodicity among rookeries.

The results show a clear bimodal distribution of tail lengths at $>75 \mathrm{~cm}$ CCL, suggesting that at this size most turtles have attained full maturity. This is consistent with the size of loggerhead females nesting in the Mediterranean (Margaritoulis et al. 2003) and males breeding at Zakynthos, Greece (Schofield et al. 2013).

In conclusion, our results complement previous studies on loggerhead turtles in the Mediterranean and support their findings of similar and more balanced sex ratios in adults and juveniles than in hatchlings. The results also suggest that adult sex ratios in foraging grounds vary according to the period of the year. In order to obtain a correct understanding of the population dynamics of Mediterranean loggerhead sea turtles, including the apparent discrepancy between hatchling and juvenile/adult sex ratios, we recommend assessing juvenile and adult sex ratios at the major foraging grounds that have not yet been investigated, such as the neritic areas in Libya, Egypt, Turkey and eastern Greece, as well operational sex ratios at all the major rookeries.

\section{ACKNOWLEDGEMENTS}

We are greatly indebted to all the fishermen who collaborated to this study and to the volunteers who supported WWF Italy's Sea Turtle Centre in Lampedusa. We thank Mariapia Ciampa, Gianluca Treglia,
Andrea Travaglini and Giovanni De Martino of the Marine Turtle Group of the SZN for their fundamental contribution to the monitoring of the loggerhead turtle presence in the South Tyrrhenian Sea and all students and collaborators for their generous contributions of time. Finally, we thank L. Cardona and S. Tomillo for their valuable comments on the first version of the manuscript.

\section{REFERENCES}

Balazs G.H. 1999. Factors to consider in the tagging of sea turtles. In: Eckert K.L., Bjorndal K.A., Abreu-Grobois F.A., Donnelly M. (eds), Research and Management Techniques for the Conservation of Sea Turtles, IUCN/SSC Marine Turtle Specialist Group Publication No. 4, pp. 101-109.

Bjorndal K.A., Bolten A.B., Martins H.R. 2000. Somatic growth model of juvenile loggerhead sea turtles Caretta caretta: duration of pelagic stage. Mar. Ecol. Prog. Ser. 202: 265-272. http://dx.doi.org/10.3354/meps202265

Bolten A.B. 1999. Techniques for measuring sea turtles. In: Eckert K.L., Bjorndal K.A., Abreu-Grobois F.A., Donnelly M. (eds), Research and Management Techniques for the Conservation of Sea Turtles, IUCN/SSC Marine Turtle Specialist Group, pp. 110-114.

Broderick A.C., Coyne M.S., Fuller W.J., et al. 2007. Fidelity and over-wintering of sea turtles. Proc. R. Soc. B Biol. Sci. 274: $1533-1538$

Bull J.J. 1980. Sex determination in reptiles. Q. Rev. Biol. 55: 3-21. http://dx.doi.org/10.1086/411613

Casale P., Margaritoulis D. 2010. Sea Turtles in the Mediterranean: Distribution, Threats and Conservation Priorities. IUCN, Gland, Switzerland.

Casale P., Gerosa G., Argano R., et al. 1998. Testosterone titers of immature loggerhead sea turtles (Caretta caretta) incidentally caught in the central Mediterranean: a preliminary sex ratio study. Chelonian Conserv. Biol. 3: 90-93.

Casale P., Freggi D., Basso R., et al. 2005. Size at male maturity, sexing methods and adult sex ratio in loggerhead turtles (Caretta caretta) from Italian waters investigated through tail measurements. Herpetolog. J. 15: 145-148.

Casale P., Lazar B., Pont S., et al. 2006. Sex ratios of juvenile loggerhead sea turtles Caretta caretta in the Mediterranean Sea. Mar. Ecol. Prog. Ser. 324: 281-285 http://dx.doi.org/10.3354/meps324281

Casale P., Broderick A.C., Freggi D., et al. 2012. Long-term residence of juvenile loggerhead turtles to foraging grounds: 
a potential conservation hotspot in the Mediterranean. Aquat. Conserv: Mar. Freshw. Ecosyst. 22: 144-154.

http://dx.doi.org/10.1002/aqc.2222

Casale P., Freggi D., Cinà A., et al. 2013. Spatio-temporal distribution and migration of adult male loggerhead sea turtles (Caretta caretta) in the Mediterranean Sea: further evidence of the importance of neritic habitats off North Africa. Mar. Biol. 160: 703-718. http://dx.doi.org/10.1007/s00227-012-2125-0

Charnov E.L., Bull J. 1977. When is sex environmentally determined? Nature 266: 828-830. http://dx.doi.org/10.1038/266828a0

Clusa M., Carreras C., Pascual M., et al. (in press). Fine-scale distribution of juvenile Atlantic and Mediterranean loggerhead turtles (Caretta caretta) in the Mediterranean Sea. Mar. Biol.

Dodd C.K.J. 1988. Synopsis of the biological data on the loggerhead sea turtle Caretta caretta (Linnaeus 1758). U.S. Fish Wildl. Serv., Biol. Rep. 88(14).

Fisher R.A. 1930. The genetical theory of natural selection. Dover Publications, New York.

Freedberg S., Wade M.J. 2001. Cultural inheritance as a mechanism for population sex-ratio bias in reptiles. Evolution 55: 1049-1055.

http://dx.doi.org/10.1554/0014-3820(2001)055[1049:CIAAMF 12.0.CO;2

Garofalo L., Mastrogiacomo A., Casale P., et al. 2013. Genetic characterization of central Mediterranean stocks of the loggerhead turtle (Caretta caretta) using mitochondrial and nuclear markers, and conservation implications. Aquat. Conserv: Mar. Freshw. Ecosyst. 23: 868-884. http://dx.doi.org/10.1002/aqc.2338

Godley B.J., Broderick A.C., Downie J.R., et al. 2001a. Thermal conditions in nests of loggerhead turtles: further evidence suggesting female skewed sex ratios of hatchling production in the Mediterranean. J. Exp. Mar. Biol. Ecol. 263: 45-63. http://dx.doi.org/10.1016/S0022-0981(01)00269-6

Godley B.J., Broderick A.C., Mrosovsky N. 2001b. Estimating hatchling sex ratios of loggerhead turtles in Cyprus from incubation durations. Mar. Ecol. Prog. Ser. 210: 195-201. http://dx.doi.org/10.3354/meps210195

Hays G.C., Fossette S., Katselidis K.A., et al. 2010. Breeding periodicity for male sea turtles, operational sex ratios, and implications in the face of climate change. Conserv. Biol. 24: 1636-1643. http://dx.doi.org/10.1111/j.1523-1739.2010.01531.x

Heppell S.S., Crowder L.B., Crouse D.T., et al. 2003. Population models for Atlantic loggerheads: past, present, and future. In: Bolten A.B., Witherington B.E. (eds), Loggerhead Sea Turtles, Smithsonian Books, pp. 255-273.

Hochscheid S., Travaglini A., Maffucci F., et al. 2013. Since turtles cannot talk: What beak movement sensors can tell us about the feeding ecology of neritic loggerhead turtles, Caretta caretta. Mar. Ecol. 34: 321-333. http://dx.doi.org/10.1111/maec.12018

Janzen F.J., Paukstis G.L. 1991. Environmental sex determination in reptiles: ecology, evolution, and experimental design. Q. Rev. Biol. 66: 149-179. http://dx.doi.org/10.1086/417143

Kaska Y., Ilgaz C., Ozdemir A., et al. 2006. Sex ratio estimations of loggerhead sea turtle hatchlings by histological examination and nest temperatures at Fethiye beach, Turkey. Naturwissenschaften 93: 338-343 http://dx.doi.org/10.1007/s00114-006-0110-5

Katselidis K.A., Schofield G., Stamou G., et al. 2012. Females first? Past, present and future variability in offspring sex ratio at a temperate sea turtle breeding area. Anim. Conserv. 15: 508-518. http://dx.doi.org/10.1111/j.1469-1795.2012.00543.x

Maffucci F., D’Angelo I., Hochscheid S., et al. 2013. Sex ratio of juvenile loggerhead turtles in the Mediterranean Sea: Is it really 1:1? Mar. Biol. 160: 1097-1107. http://dx.doi.org/10.1007/s00227-012-2160-x

Margaritoulis D., Argano R., Baran I., et al. 2003. Loggerhead turtles in the Mediterranean Sea: present knowledge and conservation perspectives. In: Bolten A.B., Witherington B. (eds), Biology and Conservation of Loggerhead Sea Turtles, Smithsonian Institution Press, pp. 175-198.

Miller J.D. 1997. Reproduction in sea turtles. In: Lutz P.L., Musick J.A. (eds), The Biology of Sea Turtles, CRC Marine Science
Series, CRC Press, Inc., pp. 51-81.

Mrosovsky N. 1994. Sex ratios of sea turtles. J. Exp. Zool. 270: $16-27$. http://dx.doi.org/10.1002/jez.1402700104

Mrosovsky N., Provancha J. 1992. Sex ratio of hatchling loggerhead sea turtles: data and estimates from a 5-year study. Can. J. Zool. 70: $530-538$ http://dx.doi.org/10.1139/z92-080

Mrosovsky N., Baptistotte C., Godfrey M.H. 1999. Validation of incubation duration as an index of the sex ratio of hatchling sea turtles. Can. J. Zool. 77: 831-835. http://dx.doi.org/10.1139/z99-039

Oz M., Erdogan A., Kaska Y., et al. 2004. Nest temperatures and sex-ratio estimates of loggerhead turtles at Patara beach on the southwestern coast of Turkey. Can. J. Zool. 82: 94-101. http://dx.doi.org/10.1139/z03-200

Rees A.F., Margaritoulis D. 2004. Beach temperatures, incubation durations and estimated hatchling sex ratio for loggerhead sea turtle nests in southern Kyparissia bay, Greece. Testudo 6: 23-36.

Rees A.F., Margaritoulis D., Newman R., et al. 2013. Ecology of loggerhead marine turtles Caretta caretta in a neritic foraging habitat: Movements, sex ratios and growth rates. Mar. Biol. 160: 519-529. http://dx.doi.org/10.1007/s00227-012-2107-2

Schofield G., Lilley M.K.S., Bishop C.M., et al. 2009. Conservation hotspots: implications of intense spatial area use by breeding male and female loggerheads at the Mediterranean's largest rookery. Endang. Species Res. 10: 191-202. http://dx.doi.org/10.3354/esr00137

Schofield G., Hobson V.J., Fossette S., et al. 2010. Fidelity to foraging sites, consistency of migration routes and habitat modulation of home range by sea turtles. Divers. Distrib. 16: 840-853. http://dx.doi.org/10.1111/j.1472-4642.2010.00694.x

Schofield G., Dimadi A., Fossette S., et al. 2013. Satellite tracking large numbers of individuals to infer population level dispersal and core areas for the protection of an endangered species. Divers. Distrib. 19: 834-844. http://dx.doi.org/10.1111/ddi.12077

Stewart K.R., Dutton P.H. 2011. Paternal genotype reconstruction reveals multiple paternity and sex ratios in a breeding population of leatherback turtles (Dermochelys coriacea). Conserv. Genet. 12: 1101-1113 http://dx.doi.org/10.1007/s10592-011-0212-2

Tiwari M., Bjorndal K.A. 2000. Variation in morphology and reproduction in loggerheads, Caretta caretta, nesting in the United States, Brazil, and Greece. Herpetologica 56: 343-356.

Uçar A., Kaska Y., Ergene S., et al. 2012. Sex ratio estimation of the most eastern main loggerhead sea turtle nesting site: Anamur beach, Mersin, turkey. Isr. J. Ecol. Evol. 58: 87-100. http://dx.doi.org/10.1560/IJEE.58.1.87

Wibbels T. 1999. Diagnosing the sex of sea turtles in foraging habitats. In: Eckert K.L., Bjorndal K.A., Abreu-Grobois F.A., Donnelly M. (eds), Research and Management Techniques for the Conservation of Sea Turtles, IUCN/SSC Marine Turtle Specialist Group Publication No. 4, pp. 139-143.

Wibbels T. 2003. Critical approaches to sex determination in sea turtles. In: Lutz P.L., Musick J.A., Wyneken J. (eds), The Biology of Sea Turtles. Volume II., CRC Marine Biology Series, CRC Press, Inc., pp. 103-134.

Wright L.I., Stokes K.L., Fuller W.J., et al. 2012. Turtle mating patterns buffer against disruptive effects of climate change. Proc. R. Soc. B Biol. Sci. 279: 2122-2127.

Yntema C.L., Mrosovsky N. 1980. Sexual differentiation in hatchlings loggerheads (Caretta caretta) incubated at different controlled temperatures. Herpetologica 36: 33-36.

Zar J.H. 1999. Biostatistical analysis. Fourth edition. Prentice-Hall Inc., Upper Saddle River, New Jersey.

Zbinden J.A., Davy C., Margaritoulis D., et al. 2007. Large spatial variation and female bias in the estimated sex ratio of loggerhead sea turtle hatchlings of a Mediterranean rookery. Endang. Species Res. 3: 305-312. http://dx.doi.org/10.3354/esr00058

Zbinden J.A., Bearhop S., Bradshaw P., et al. 2011. Migratory dichotomy and associated phenotypic variation in marine turtles revealed by satellite tracking and stable isotope analysis. Mar. Ecol. Prog. Ser. 421: 291-302. http://dx.doi.org/10.3354/meps08871 